\title{
APRESENTAÇÃO/PRESENTATION FIGURAÇÕES
}

Os pesquisadores do campo das linguagens têm dedicado tempo considerável a refletir sobre temas da linguagem a partir de práticas rotineiras ou seletivas e suas características culturais, como os que se apresentam nesta edição: direitos humanos e homofobia, interação humana em ambiente relativo a questões de saúde, divulgação científica em meio informatizado, questões sempre atuais que remetem ao culto ao corpo tendo o feminino como tópico, a forma de promover a emoção em gêneros e meios diversos, o professor de língua estrangeira e suas representações profissionais. Some-se a esse conjunto um material teórico como contraparte na rotina da humanidade: a discussão conceitual de dialogismo e intertextualidade em sua aproximação ou distanciamento.

Escolhemos olhar esses desenvolvimentos utilizando uma tela especial, que, em seu trabalho sociológico-histórico, Norbert Elias ([1983]2001)* chamou de figurações, figurações específicas estabelecidas por interdependência de pessoas (modos de convivência, valores, crenças, normas culturais), pelas quais, no quadro de sua pesquisa sobre a sociedade de corte do Ancien Régime, ele explica como se desenvolveu e se manteve a corte real na França, tendo como ápice o reinado de Luís XIV.

Nenhuma sociedade é um fenômeno existente fora dos indivíduos e das relações que mantêm, em pequenos ou grandes grupos, entre si e nos intercâmbios com os outros, estabelecendo um modo político de vida com sua vertente ideológica e imaginária, em que há parcial convergência tanto quanto divergência e confrontos, formas de uso do espaço (físico, virtual, psicológico) congregadas ao tempo (cronológico, linguístico, psicológico). Em suma, estamos falando de diferenças de modos conviviais nos mundos espaçotemporais possíveis (que podem ser utópicos), nesse processo de entrelaçamento complexo que é a interação humana.

As designações que utilizamos para falar desse relacionamento estão aí para testemunhar figurações: racismo, humor, violência, poder, cognição, direitos humanos, homofobia, ressentimento, devoção, sensibilidade, solidariedade - formas que podem se aproximar ou se afastar dos polos que mais ou menos reconhecemos e aceitamos. O modo de vida mais ou menos benévolo ou mais ou menos malévolo depende das figurações criadas, estabelecidas ou desmanchadas no grande tempo. Inclinações, sentimentos e comportamentos testemunham as formas de vida e os laços (sempre um pouco frágeis) estabelecidos ou desmanchados. A memória do humano se funda e continua a ressoar em certas repetições consagradas pelo senso comum (que não é comum universalmente, mas existe num fundo de memória, pronto a aflorar com os acontecimentos.

Nessa vaga humana das repetições que vão se consagrando, a partir de uma faísca geradora que "pega", consagramos aquela unidades que Dawkins ([1976]2007)

\footnotetext{
* ELIAS, Norbert. A sociedade de corte. Investigação sobre a sociologia da realeza e da aristocracia de corte. Trad. Pedro Süssekind. Pref. Roger Chartier, trad. André Telles. Rio de Janeiro: Zahar, [1983] 2001.

** DAWKINS, Richard. O gene egoísta. Trad. Rejane Rubino. São Paulo: Cia das Letras, [1976] 2007.
} 
designou como memes, replicadores culturais correlatos dos genes, hoje pululando nas redes sociais. Em jogo: a memória, a identidade flutuante, a subjetividade nesses encontros e desencontros humanos - encontros que testemunham a construção e desenvolvimento da vida com seu corpo simbólico, no embate entre as coerções e as pretensas liberdades. Unidades e temas aparecem todos nesse campo semeado e adubado: palavras, expressões, ideias, tendências, slogans, teorias, provérbios. Solo ideológico, escorregadio, no qual o deslizamento é fatal.

Detectamos aqui variedades de interação, com suas possíveis figurações.

a) Direitos humanos e homofobia - No longo processo de se estabelecer direitos humanos, alguma coisa perdura: o preconceito, neste caso a homofobia, que tem uma memória estabelecida e um princípio de verdade em funcionamento: eu estou certo, você está errado (segue contra a natureza). Um na ofensiva, outro na defensiva. Estabele-se o confronto.

b) A interação humana no tratamento de questões de saúde, envolvendo notícias diagnósticas - É interação delicada e sujeita a sustos, que pede atitude "pedagógica", preparação no trabalho interacional e tato, especialmente se as notícias não são favoráveis.

c) Divulgação científica - Tem mais de uma face, e mais de um ângulo de visão e de leitura. Muitos fazem divulgação (produzindo ou repetindo). $\mathrm{Na}$ Web, em redes sociais, todos produzem. E deslocam as notícias já a partir do título; títulos podem virar notícia. Parece importante poder circular, chegar a alguém.

d) Culto ao corpo - As representações do corpo feminino envolvem toda a sociedade, as relações memoriais e a tentativa de estabelecer, em certas figurações, novos modelos a partir da cultura de consumo, comandada por distanciamento e apelo que não presume uma interação direta, e por isso mesmo mais insidiosa em seu discurso de construção identitária.

e) Promoção da emoção - Tem-se aqui uma interação distanciada, em gênero fílmico de TV, portanto os produtores usam de estratégias especiais para a conquista do telespectador desconhecido, que vai assistir aos embates passo a passo. O suspense é essencial. É uma conquista.

f) Professor e suas representações - É "um" que reflete mas ocupa diferentes posições (divide-se) ao lidar com a memória (sua história), em que se multiplicam as vozes de seu mundo vivido. A tecnologia multiplica sua clivagem e o leva a movimentos de resistência. A meta é uma nova constituição subjetiva, menos flutuante.

g) Reflexão teórica: dialogismo e intertextualidade - Ensaia-se a interação, em seu teor teórico, como uma forma de compreensão das filigranas das noções que ocorrem nas várias perspectivas. É preciso saber de onde vêm as vozes, e as relações dialógicas internas são o âmago da própria dialogicidade - do discurso.

Esperamos que nossa interação tenha se processado convenientemente, conduzindo à leitura dos textos publicados nesta edição.

\section{Os Editores}

